University of Warwick institutional repository: http://go.warwick.ac.uk/wrap This paper is made available online in accordance with publisher policies. Please scroll down to view the document itself. Please refer to the repository record for this item and our policy information available from the repository home page for further information.

To see the final version of this paper please visit the publisher's website. Access to the published version may require a subscription.

Author(s): Clare Anderson

Article Title: Gender, identity, mobility: an introduction to the annual conference edition of the British Association for South Asian Studies Year of publication: 2009

Link to published version: http://dx.doi.org/

10.1080/09584930802624620

Publisher statement: None 


\title{
Gender, Identity, Mobility: an introduction to the annual conference edition of the British Association for South Asian Studies
}

\author{
Clare Anderson \\ University of Warwick \\ clare.anderson@warwick.ac.uk
}

The $22^{\text {nd }}$ Annual Conference of the British Association for South Asian Studies (BASAS) took place at the University of Leicester, 26-8 March 2008. Co-convened by Prashant Kidambi (School of Historical Studies, University of Leicester) and Clare Anderson (Department of Sociology, University of Warwick), it marked an important moment in the history of the association, for it was the first conference held under the auspices of two newly merged societies - the British Association for South Asian Studies and the South Asian Studies Association. The new BASAS is grant-aided by the British Academy, and as such it seeks to represent and advocate for British-based research of and in South Asia, and to combine financial assistance with support for research. It is an umbrella for a range of activities, and promises both to invigorate and to raise the profile of British-based research of and in South Asia: within Britain and the UK, across Europe, and internationally. ${ }^{1}$ The 2008 conference was significant for another reason to, for it was the first time that this annual BASAS event had met in Leicester, one of Europe's most multi-cultural cities and home to a large population of South Asian descent. It was somehow apt that over one hundred scholars from across the disciplines of anthropology, geography, history, literature, sociology, philosophy, and political science, and from over a dozen countries in Europe, North America, and South and East Asia, met in a city which is celebrated for its diversity and community cohesion. The conference programme incorporated 25 panels, some open and others themed, and one special BASAS session convened by BASAS chair Graham Chapman, 'Water and Mis-Development'. It was a special pleasure to introduce the eminent Indian anthropologist, Vishvajit Pandya, as keynote speaker. His anthropological reading of tribal violence in the Andaman Islands - 'Signifying Practices: the violent Other in placeless-place' - was enthusiastically received by the conference delegates. $^{2}$

This special conference edition of Contemporary South Asia - published by Taylor and Francis which generously part sponsors the annual meeting - brings together something of the disciplinary range and geographical and temporal scope of the conference papers presented and discussed in Leicester. Paper themes ranged from histories of medicine, childhood, and colonization to debates around interactions between state and society, the aftermath of the 2004 tsunami, and critical readings of 'Queer' Bollywood. Panel titles included 'The Genealogy of Colonial Discourse', 'Gender, History, Representation: subaltern voices in and of South Asia', 'Nationalism, Identity, and Ethnic Conflict in Sri Lanka', 'Dalits in the Indian Economy', 'Continuity and Change: a comparative analysis of contemporary India and Pakistan', and 'A New India? Studying India in the long twentieth century'. The annual conference provides an excellent opportunity for delegates to meet, to work through ideas, and to develop current and future research projects; the meeting in

\footnotetext{
${ }^{1}$ The BASAS webpage has now shifted to http://www.britac.ac.uk/institutes/SSAS/about.htm

${ }^{2}$ The conference programme and panel abstracts are available through the BASAS website: http://www.basas.ac.uk/conference08/2008_Annual_Conference_Programme.htm, accessed 1 October 2008.
} 
Leicester was no exception. Its informal yet strongly international and interdisciplinary feel makes it a valuable forum for experience faculty as well as postgraduates and early-career researchers who wish to present papers in a supportive and encouraging intellectual environment.

The volume explores some of the interconnected themes that emerged during the conference across a range of disciplines and historical and contemporary contexts. It represents BASAS members' vigour and depth in research in the humanities and social sciences, with the papers ranging geographically across much of South Asia India, Bangladesh, Sri Lanka, and Pakistan - to East Africa, Britain, and the USA. The papers focus on the gendered construction of identities in the context of geographical and / or social mobility, linking gender, identity, and movement across space and society to questions of rights, nationhood, and citizenship. The articles presented here stress in particular the need to understand and to develop further ideas around 'woman' as a relational social category and to trace the intersection of local practices with broader national and international social concerns and transformations. Particularly refreshing is their focus - whether historical, literary or ethnographic - on individual and collective experiences of state and society. Women emerge as a central conduit for the formation of community-based identities; colonialism and its aftermath loom large, reminding us of the need to situate and to understand historically what we might want to celebrate, challenge or confront in the present day.

The volume opens with Nico Slate's prize winning paper on the American travels of feminist, socialist, and anti-colonial activist, Kamaladevi Chattopadhyaya, during the 1940s. He frames her encounters with feminists and African Americans in the USA as a form of 'coloured cosmopolitanism' that encouraged social unity across 'racial' boundaries. He argues that Chattopadhyaya was a powerful conduit for critiques of America, and that in raising awareness of the civil rights movement in her many published essays and writings, she played an important role in forcing domestic change. Chattopadhyaya embodied the intersectionality of multiple oppressions around 'race' and gender, and through her own imprisonment came to symbolise the incarcerated nation.

Joanna Herbert's article takes up one of the underpinning themes of Slate's paper: the use of individual histories as a methodological tool for historical and social analysis. Herbert draws on the life stories of first generation Ugandan Asians in London and Leicester to explore their experiences of expulsion from East Africa in 1972. She argues that the Ugandan Asian diaspora represent their collective experiences through a lens that refracts ideas of masculine pioneering through those of female vulnerability and loss, so producing 'woman' as a relational category of gendered analysis. However, she shows how this collective identity cloaks a range of experiences amongst Ugandan Asian women. Though suffering was a central theme in their remembered histories of dispossession and expulsion, their narratives reveal a sense of active agency and dynamic mobility.

We remain in the Indian Ocean for Stephanie Jones's reading of allegory and realism in the first South Asian East African novel in English, Bahadur Tejani's Day After Tomorrow (1971). Jones discusses some of the complexities and contradictions of the text by positioning it within its political and literary context and against postcolonial nation discourse theory. She argues that in its symbolism the novel seems to suggest the desirability of (South Asian) biological and cultural assimilation within a dominant pre-historic 'African sensibility' where Africans were associated with femininity and South Asians with masculinity. This gendering was both determined by and enacted through the tropes of 'race' and 'class', which linked the African to a 
timeless, pastoral ideal, and the Asian to "the "white" colonial and neo-colonial exploiter' - or even 'Jew'. And yet, as Jones shows, Tejani also offers a more material portrait of the novel's central female character, Nanziri, as 'a capable woman doing ordinary things'. She suggests that Tejani's concern with everyday practices reveals the 'fundamental incoherence of national discourse' - but also suggests his commitment to the possibility of more inclusive nation-based African solidarities.

Meena Dhanda deals with the issues of gender, identity, and mobility through am ethnographic frame, exploring the ways in which the nature and meaning of caste is negotiated rather than given or invented. Her focus is on dalit Punjabi youth; she unpicks carefully the multiple positions through which they negotiate their sense of social place in the UK (Wolverhampton) and in India (Punjab). Sexual relationships, intimacy, and marriage emerge as central themes in her analysis, for it is here that stark differences between the two communities emerge. Dhanda shows that caste border-crossings are more common amongst Indian Punjabis than British ones, revealing the nature of a perhaps surprising interconnection of geographical and social movement. The political and the personal become interlocked, with identities enveloped within a range of religious, national, and ideological (notably feminist) locations. As she cautions: 'Identity assertion may be seen as a mode of mobilization used by dalits but it would be a mistake to see it as their end.'

The final two articles in the volume explore women's experiences of and responses to two devastating natural disasters that affected the Bay of Bengal in 2004. In discussing widespread flooding in Bangladesh, Keiko Ikeda invokes a genderfocused analysis in her elaboration of community-based natural disaster risk management. She shows that women and men experience natural disasters differently, and argues that their concerns should therefore be taken into account by local agents of development. As Ikeda draws out the multiple difficulties and possibilities surrounding the incorporation of women in 'traditional' structures of authority, once again we see gender as a relational social category. Moreover, in her assessment of the gaps between women's concerns and risk-reduction action, Ikeda offers important and policy relevant suggestions for policies and practices in and of development.

Katharina Thurneer is also concerned with the experiences of people caught in crisis, in her case the Sri Lankan communities affected by the devastating tsunami of December 2004. It is estimated that 35,000 Sri Lankans - and more women than men - lost their lives in the disaster, with one million made homeless. Thurnheer shows, however, that far from being passive recipients of what is sometimes called a second tsunami of international aid, Sri Lankan communities used access to financial and other resources as a means of strategic self-positioning. In this way, they were able to nurture 'hopes amid destruction' in their negotiations with 'a range of connected constraints and possibilities'. Gender relations informed the interaction between local agendas and external interventions in significant ways, and were themselves in constant transformation within a wide frame of social change.

These articles highlight three interlinked themes that emerged during the BASAS Annual Conference 2008, and so show the intellectual possibilities of assembling papers from across historical time, geographical space, and oft-times disciplinary distance. There is a remarkable synergy to the authors' theoretical frameworks and to their connected thematic concerns. Thus the papers are suggestive of the significance and broad appeal of both interdisciplinarity and the need to think through the historical rootedness of contemporary concerns, in local and global perspective. Moreover, they serve as an important reminder that gender must remain central to research in and of South Asia. 


\section{Acknowledgements}

The editor of this special issue would like to thank Prashant Kidambi and Sandeep Bakshi, who co-organised and co-ran the 2008 conference; the conference delegates; the contributors to and peer reviewers of this volume; the BASAS Executive Committee and Chair, Graham Chapman for their support; and, John Zavos, editor of Contemporary South Asia. 